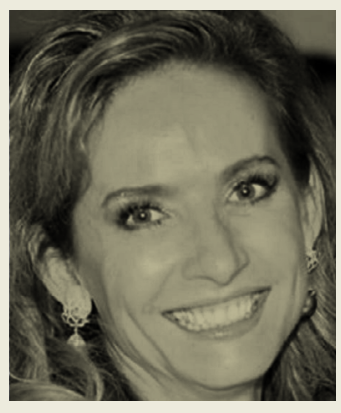

\title{
COMPLIANCE OR
} NON-COMPLIANCE?

Por que muitos executivos se esquecem dos princípios éticos e morais? O que leva uma empresa a ignorar seu código de conduta de responsabilidade social? É possível recuperar a reputação de uma corporação após um escândalo de corrupção? E a imagem de um executivo após um escândalo financeiro? Essas indagações são mais oportunas do que nunca. Os recentes escândalos de empresas como Nissan, Petrobras, FIFA, JBS, Volkswagen e Odebrecht demonstram que falhas nos programas de compliance colocam em jogo a implementação dos ideais de responsabilidade social corporativa, tão aclamados pelo mundo empresarial nos dias de hoje. Após os escândalos que expuseram essas empresas globalmente, quão credível é a iniciativa dos seus códigos de ética e de responsabilidade social? Integrar ambos é um desafio que pode ser vencido por meio de um programa de compliance eficiente e competente. Para retomar a legitimidade, as empresas precisam adotar novas regras de conformidade ou compliance e remover os culpados, não importa quem sejam. Mas o que é importante nem sempre é fácil de ser implementado.

Uma postura empresarial ética nos negócios integrada a uma abordagem de responsabilidade social corporativa e combate à corrupção num sentido amplo é fortemente aguardada pela sociedade contemporânea. Isso faz com que o papel das empresas seja mais complexo do que no passado. Compliance - do inglês to comply with - é comumente entendida como estar em conformidade com leis e regulamentos externos e internos. Parece que quase diariamente os jornais trazem histórias de grandes empresas investigadas por não compliance (fraude, corrupção, lavagem de dinheiro etc.) e que pagarão multas e penalidades importantes. Quase todas essas histórias vêm acompanhadas de comunicados à imprensa denunciando o comportamento antiético e anunciando uma série de medidas para garantir que a conduta inadequada não ocorrerá novamente. Quanto maior o desastre, maiores serão a atenção e o cuidado. Entre essas medidas, há sempre menção à contratação de profissionais de compliance para reforçar as equipes internas. Todavia, por que muitas empresas escolhem a conduta "errada", apesar da existência de programas de compliance? Logicamente, todos sabiam que o software da Volkswagen, que mascarava os níveis de emissão de poluentes, geraria grandes perdas. Era impossível cobrir essa fraude por muito tempo...

Programas de compliance desenvolvidos e implementados de modo adequado e eficiente resultam em baixa incidência de falhas de conformidade e, portanto, sem ação de órgãos reguladores ou reação negativa da imprensa ou sociedade civil. Como iniciativas de compliance são bem-sucedidas, muitos não veem necessidade de manter recursos relevantes ou investimentos direcionados a esses programas. Isso porque não se dá crédito para coisas que não acontecem. E aí está o grande erro, que só aparece após uma falha de conformidade, a qual vai gerar exposição negativa na mídia, danos à reputação, penalidades e multas, seguidos de recursos ao departamento de compliance, na tentativa de agradar tanto aos órgãos reguladores quanto à mídia e à sociedade.

Não é fácil demonstrar a importância nem o retorno do investimento de compliance para impedir que seus programas tenham seus orçamentos cortados e equipes sejam sacrificadas em nome de ganhos financeiros de curtíssimo prazo. A atenção não deve recair apenas sobre o que acontece. Um programa de compliance eficiente é a melhor opção às empresas e aos executivos para evitar processos judiciais e escândalos. 